\title{
Pengaruh Illegal Movie Streaming Terhadap Popularitas Film Bagi Mahasiswa
}

\author{
Vivia Ellysinta, Wilson Vernando, Kelvin Kurniawan, Junifer \\ Universitas Internasional Batam \\ 1831028.vivia@uib.edu
}

\begin{abstract}
Abstrak
Kata Internet sudah tidak asing lagi bagi kita semua. Adanya perkembangan teknologi di dunia kini dengan bantuan internet memberi banyak fasilitas yang menghibur dan memudahkan kehidupan banyak orang, terutama di dunia hiburan. Dalam dunia perfilman, terdiri dari banyak macam film, ada beberapa film yang memang disediakan online dengan gratis, dan ada juga film yang hanya bisa ditonton secara langsung di bioskop dengan dipungut biaya. Walaupun begitu, film-film tersebut kerap kita temui di Internet. Salah satu fasilitas di internet yang sangat mudah diakses dan banyak dilkakukan oleh orang, terutama bagi mahasiswa Kota Batam adalah melakukan Streaming film bajakan secara online. Karena mudah dan gratis, banyak orang lebih memilih untuk melakukan Illegal Streaming ini. Walaupun aksi ini bersifat Illegal. Popularitas dari film pun akan meningkat secara tidak langsung dan tanpa sadar. Hasil dari penelitian ini akan menunjukkan bahwa popularitas film berpengaruh dengan adanya Illegal Movie Streaming di kalangan mahasiswa Kota Batam.
\end{abstract}

Kata Kunci: Internet; Film; Illegal Movie Streaming; Popularitas Film; Mahasiswa

\begin{abstract}
The word internet has been familiar to us all. The existence of technological developments in the world now with the help of the internet provides many facilities that entertain and facilitate the lives of many people, especially in the entertainment world. In the world of movies, movies consists many kinds of movies, there are numbers of films that are provided online for free, and there are also films that can only be watched live in theaters and charged. Even so, we can find them easily on the Internet. One of the facilities on the internet that is very easily accessed and widely carried out by people, especially for Batam City students, is to stream movies online. The only reason is because it's easy and free, many people prefer to do Illegal Streaming. Despite they are actually Illegal. The popularity of the film will increase indirectly and unconsciously because of it. The results of this study will show that the popularity of the movies effects or influences the presence of Illegal Movie Streaming among Batam City students.
\end{abstract}

Keywords: Internet; Movie; Illegal Movie Streaming; Movie Popularity; Student

http://ejournal.urindo.ac.id/index.php/TI 


\section{PENDAHULUAN}

Film adalah sebuah media komunikasi yang sampai saat ini masih sangat populer dan marak di dunia. Di zaman modern ini, terdapat berbagai macam film dengan perspektif yang berbeda-beda, baik sebagai media edukasi, seni, serta industri pada media massa. Film pertama kali dipertontonkan untuk khalayak umum dengan membayar berlangsung di Grand Cafe Boulevard de Capucines, Paris, Perancis pada 28 Desember 1895. Peristiwa ini sekaligus menandai lahirnya film dan bioskop di dunia (Sutadi, 2010).

Adanya perkembangan teknologi di dunia dengan bantuan dari Internet menguntungkan konsumen yang menginginkan cara yang nyaman untuk melihat dan mendengar informasi dan konten hiburan pada berbagai perangkat elektronik. Teknologi baru menawarkan potensi untuk membantu pemegang hak cipta mempromosikan karya kreatif mereka untuk alasan artistik, pendidikan, dan komersial (Apriyani, 2020). Namun, teknologi baru dapat meningkatkan risiko pelanggaran hak-hak pemegang hak cipta. Hal tersebut disebabkan karena mereka yang sering memberikan cara yang lebih cepat, lebih murah, dan lebih mudah untuk terlibat dalam reproduksi, distribusi, dan kinerja publik atas karya berhak cipta (BP Lawyers, 2018). Salah satu teknologi baru ini memungkinkan "streaming" konten hak cipta melalui Internet dari situs web ke pengguna akhir.

Ada banyak situs web streaming yang sah seperti Hulu, Netflix, YouTube yang menawarkan aliran sesuai permintaan film (Wikipedia, 2020). Namun, teknologi streaming juga dapat disalah gunakan untuk memfasilitasi pelanggaran hak cipta online. Situs web yang disebut "nakal" berfungsi sebagai alternatif dari situs web yang diotorisasi (Indonesia, 2020). Dengan sengaja mengalirkan konten yang dilindungi hak cipta yang diperoleh secara tidak sah kepada pengguna.

Pembajakan film sudah menjadi hal yang serius bagi industri film Indonesia. Secara nasional industri film mengalami kerugian hingga Rp5 triliun per tahun. Hal ini terjadi karena adanya peralihan penonton film bioskop. Mereka lebih memilih streaming melalui situs streaming film ilegal (Raharjo, 2018). Dengan menawarkan kepada konsumen alternatif yang melanggar hukum untuk melihat konten streaming, situs web jahat ini dapat mengurangi jumlah orang yang akan mengunjungi penyedia materi berhak cipta yang sah (Burdatun, 2016).

Film Indonesia memiliki beragam produk yang menyatukan budaya masyarakat masa kini. Dan dengan adanya perkembangan teknologi informasi yang begitu cepat, sangatlah mudah untuk masyarakat dalam mengakses ke dalam dunia perfilman. Sehingga popularitas dari film 
itu sendiri pun semakin lama akan semakin berkembang dan meningkat. Saat ini tempattempat seperti bioskop pun semakin digandrungi setiap orang dan menjadi sasaran utama masyarakat terutama bagi anak muda masa kini. Perfilman pun semakin meluas dan menjadi media terkemuka yang diminati banyak masyarakat Indonesia (Wijiharjono, 2018).

Pemerintah di Kota Batam mendorong industri perfilman setempat untuk terus berkembang, hingga dapat menembus pasar di Asia (Silaban, 2019). Potensi industri perfilman Batam sangat besar, apalagi dengan adanya studio film di Batam yang terkenal di kalangan Indonesia dan di Kota Batam sendiri. Mahasiswa Kota Batam telah cukup banyak memproduksi film yang berkualitas baik, sejumlah film lokal di Batam juga sempat menarik perhatian publik. Ketertarikan dan partisipasi dari mahasiswa Kota Batam atas industri perfilman dapat kita lihat dari kemajuan dalam perfilman di Kota Batam. Maka dari itu, tujuan utama dari penelitian ini adalah untuk menjawab apakah dengan adanya Illegal Movie Streaming dapat mempengaruhi popularitas dari film-film tersebut bagi kalangan mahasiswa di Kota Batam.

Penelitian ini didasarkan pada hasil dan metode penelitian sebelumnya. Penelitian yang menjadi dasar penelitian adalah penelitian (Kim et al., 2018) dimana penelitian tersebut membuktikan bahwa tingkat pembajakan yang moderat memiliki dampak positif yang mengejutkan pada keuntungan produsen dan kesejahteraan konsumen dengan membuat asumsi berupa pernyataan matematis dengan faktor-faktor yang dapat membuat pembajakan menjadi lebih menarik dari saluran hukum dan hanya mempersemit ke rantai pasokan yang menghadapi dua masalah: marginalisasi ganda dan pembajakan. Dalam penelitian tersebut mereka mempelajari dampak ekonomi pembajakan pada rantrai pasokan barang informasi dan memperluas literatur tentang pembajakan ke konteks informasi yang dijual pengecer. Untuk benar-benar fokus pada bagaimana eksternalitasi vertikal ini berinteraksi dengan pembajakan.

Sementara Survei yang dilakukan oleh perusahaan data dan opini publik global (Yougov, 2019) menemukan bahwa di tengahtengah booming layanan streaming online, mayoritas penduduk Indonesia lebih memilih menonton melalui situs web illegal. Hasil survei menunjukkan bahwa 63 persen responden lebih suka melakukan illegal streaming dan 62 persen dari mereka mereka telah berhenti membayar untuk layanan TV kabel. Survei juga menemukan bahwa 29 persen responden menggunakan aplikasi ilegal yang menyediakan akses ke video dan saluran TV yang di booting. 
Penelitian (Yeh, 2012) juga menganalisis undang-undang di Kongres ke-112 yang akan menyelaraskan hukuman untuk illegal streaming ataupun bentuk pelanggaran hak cipta online lainnya dan merangkum argumen untuk menentang perubahan legislatif seperti itu. Penelitian ini menyatakan bahwa menjadikan illegal streaming sebagai sebuah kejahatan yang melanggar hukum hanyalah merupakan sebuah klarifikasi teknis. Penyebaran karya orang lain secara illegal tanpa izin harus dihukum dengan cara yang sama tanpa memandang teknologi yang digunakan.

\section{METODE}

Penelitian ini memfokuskan pada pengaruh illegal movie streaming bagi kalangan mahasiswa. Penelitian ini dituju lebih spesifik ke kalangan mahasiswa se-kota Batam karena mahasiswa merupakan salah satu kalangan terbesar yang melakukan illegal movie streaming. Penelitian ini bersifat kuantitatif, dimana data yang didapatkan berupa angka ataupun data yang dapat dikonversikan menjadi angka. Kami menggunakan google form sebagai instrument penelitian, kami akan menyebarkan google form ini agar diisi oleh populasi yang sudah ditentukan dan isi yang mereka cantumkan itu sesuai dengan pendapat mereka masing-masing.

Penelitian kami menggunakan metode survey online. Kuesioner kami terdapat 13 pertanyaan umum dan 3 pertanyaan informasi pribadi responden. Populasi yang diambil untuk penelitian ini adalah mahasiswa se-kota Batam Metode yang kami gunakan adalah Cluster Proportional Random Sampling, dimana kami mengambil sebanyak 370 sampel per 11 cluster.

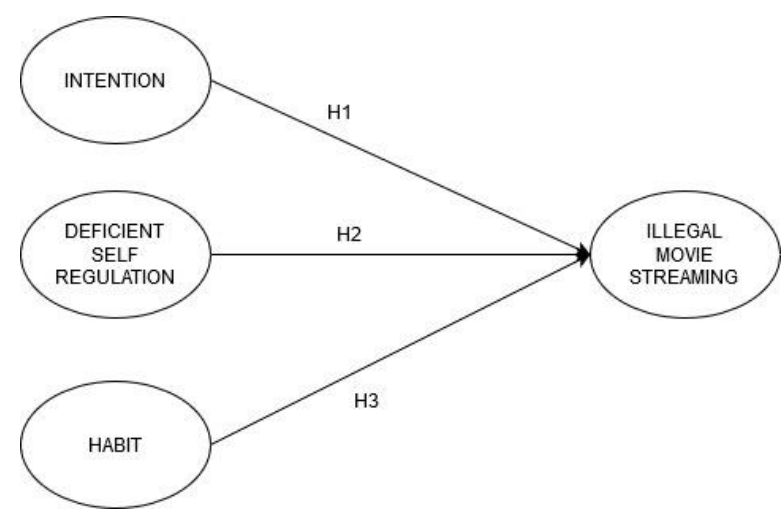

Gambar 1. Model

Hipotesis dalam penelitian ini adalah:

$\mathrm{H}^{1} \mathrm{O}$ : Intention will influence users using illegal movie streaming

$\mathrm{H}_{\mathrm{A}}^{1}$ : Intention will not influence users using illegal mobie streaming

$\mathrm{H}^{2}{ }_{0}$ : Deficient self-regulation will positively influence information sharing intention among user

$\mathrm{H}^{2} \mathrm{~A}$ : Deficient self-regulation will not positively influence information sharing intention among user

$\mathrm{H}^{3}{ }_{0}$ : Habit will influence users using illegal movie streaming

$\mathrm{H}_{\mathrm{A}}^{3}$ : Habit will not influence users using illegal movie streaming

Penelitian ini terdapat 4 Variabel, yaitu: IT Affordance, Deficient Self-Regulation, Habit and Illegal Movie Streaming. Di 4 variabel ini terdapat lagi dimensi Intention di variabel 
Intention, Deficient Self-Regulation di variabel Deficient Self-Regulation, Habit di variabel Habit dan Illegal Movie Streaming di variabel Illegal Movie Streaming.

\begin{tabular}{|c|c|}
\hline Variabel & Indikator \\
\hline \multirow{4}{*}{ Intention } & Saya berniat menonton movie melalui illegal movie stream \\
\hline & Saya berencana menonton movie melalui illegal movie stream \\
\hline & Saya berharap dapat menonton movie melalui illegal movie streaming \\
\hline & Source: Joy Ng Xue Qi (2017) \\
\hline \multirow{5}{*}{ Deficient Self Regulation } & Saya terus menerus berpikir tentang menonton movie ketika saya tidak bisa melakukannya \\
\hline & Saya mengalami kesulitan mencoba menahan keinginan untuk menonton di Illegal Movie Streaming \\
\hline & Ketika saya sudah lama tidak melakukan illegal movie streaming, saya akan selalu keingat untuk melakuke \\
\hline & Saya merasa sulit mengontrol perilaku saya untuk tidak melakukan Illegal Movie Streaming \\
\hline & Source: loy Ng Xue Qi (2017) \\
\hline \multirow{4}{*}{ Habit } & Memilih untuk melakukan Illegal Movie Streaming menjadi kebiasaan saya \\
\hline & Saya melakukan Illegeal Movie Streaming menjadi kepribadian saya \\
\hline & Menonton movie dengan illegal Movie Streaming menjadi rutinitas saya \\
\hline & Source: Joy Ng Xue Qi (2017) \\
\hline \multirow{4}{*}{ Illegal Movie Streaming } & Saya sering melakukan Illegal Movie Streaming \\
\hline & Saya telah melakukan illegal Movie Streaming secara Berkelanjutan \\
\hline & Movie yang saya nonton itu lebih banyak di illegal Movie Streaming \\
\hline & Source: Joy Ng Xue Qil (2017) \\
\hline
\end{tabular}

Gambar 2. Definisi Operasional Variabel

\section{HASIL}

Data penelitian ini mencakup total 370 mahasiswa yang ada di Batam, dengan pengujian outlier sebanyak 24 data, sehingga hasil yang diperoleh sebanyak 346 data. Berikut adalah hasil tentang topik yang telah kami teliti : 1) Persebaran Jenis Kelamin Hasil analisis dari total responden berdasarkan jenis kelamin laki-laki sebesar $52 \%$ atau 180 mahasiswa dan perempuan sebesar $48 \%$ atau 166 mahasiswa

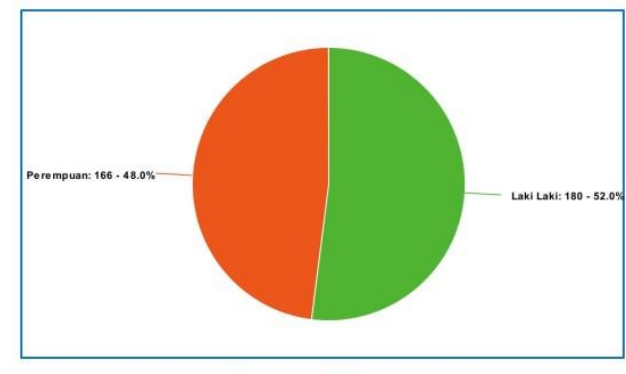

[ Laki Laki Perempuan

Gambar 3. Hasil Presentase Pie Chart

Persebaran Jenis Kelamin Mahasiswa

\section{2) Persebaran Program Studi}

Hasil analisis dari total responden berdasarkan program studi menunjukan bahwa persentase mahasiswa yang berasal dari program studi Akuntansi sebesar $22.3 \%$ atau 77 mahasiswa, Manajemen sebesar $19.7 \%$ atau 68 mahasiswa, Teknik Informasi sebesar $11.6 \%$ atau sebesar 40\%, Sistem Informasi sebesar $11.3 \%$ atau 39 mahasiswa, Pariwisata sebesar $9.5 \%$ atau 33 mahasiswa, Teknik Sipil sebesar $8.7 \%$ atau 30 mahasiswa, Ilmu Hukum sebesar 7.2\% atau 25 mahasiswa, Pendidikan Bahasa Inggris sebesar 3.2\% atau 11 mahasiswa, Arsitektur sebesar 2.6\% atau 9 mahasiswa, Teknik Elektro sebesar 2.0\% atau 7 mahasiswa, Desain Interior sebesar $0.6 \%$ atau 2 mahasiwa, Pendidikan Bahasa Mandarin sebesar $0.3 \%$ atau 1 mahasiswa, Dungeon sebesar $0.6 \%$ atau 2 mahasiwa, Hotel Management sebesar 0.3\% atau 1 mahasiswa, Art of Hand Sanitizing sebesar $0.3 \%$ atau 1 mahasiswa, dan Gaming sebesar $0.3 \%$ atau 1 mahasiswa.

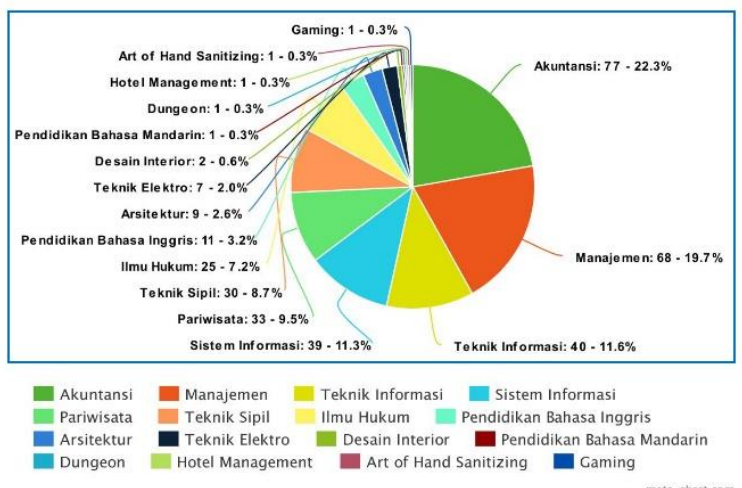

Gambar 4. Hasil Presentase Persebaran Program Studi Mahasiawa 
Uji Validitas Data yang kami lakukan dengan menggunakan Pearson Correlation dan menunjukkan bahwa setiap pertanyaan pada kuesioner yang telah disebar adalah valid.

Uji Realibitas pada penelitian ini menggunakan Cronbach's Alpha dapat diasumsikan semua construct penelitian adalah reliable karena sema berada di atas angka 0.6.

Uji R Square diperoleh sebesar 0.778, Uji F sebesar 403.945, yang berarti bahwa model tersebut cocok pada fenomena yang ada pada penelitian ini. Uji data ini juga memperoleh nilai Durbin Watson sebesar 1.631.

Selanjutnya, uji Hipotesi pada penelitian ini menunjukan angka korelasi variabel Intention memiliki konstanta senilai 0.385 dengan signifikansi $0.000<0.005$ dimana H1A diterima dan $\mathrm{H} 10$ ditolak. Variabel Intention berpengaruh secara signifikan karena dengan adanya niat untuk melakukan aksi Illegal Movie Streaming. Penelitian ini juga menunjukan angka korelasi variabel $D S R$ memiliki konstanta senilai 0.110 dengan signifikansi $0.026>0.005$ dimana $\mathrm{H} 2 \mathrm{~A}$ ditolak dan $\mathrm{H} 2 \mathrm{O}$ diterima. Variabel DSR tidak berpengaruh terhadap aksi Illegal Movie Streaming karena Illegal Movie Streaming sekarang sudah menjadi hal biasa yang dilakukan. Kemudian penelitian ini juga menunjukan angka korelasi variabel Habit memiliki konstanta senilai 0.462 dengan signifikasi $0.000<0.005$ dimana H3A diterima dan H3O ditolak. Variabel Habit juga berpengaruh secara signifikan terhadap aksi Illegal Movie Streaming karena sudah menjadi sebuah kebiasaan jika melakukan aksi Illegal Movie Streaming secara terus menerus

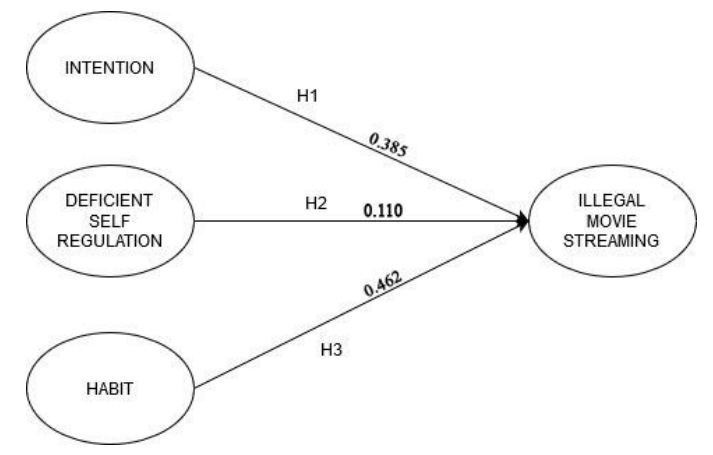

Gambar 5. Model Hasil Analisis Penelitian

\section{SIMPULAN}

Hasil penelitian ini menunjukkan bahwa sebagian besar mahasiswa di Kota Batam memang sudah banyak melakukan kegiatan Illegal Movie Streaming dan menjadi mengenal film yang sebelumnya belum diketahui. Hal tersebut didukung dengan adanya pengaruh yang secara signifikan oleh variabel Habit dan Intention pada penelitian ini. Akan tetapi, variabel Deficient Self Regulation tidak memberi pengaruh terhadap aksi Illegal Movie Streaming karena Illegal Movie Streaming di zaman sekarang sudah menjadi hal yang bersifat biasa untuk dilakukan bagi kalangan mahasiswa di Kota Batam.

Untuk melakukan pengujian terhadap penelitian ini, kami menggunakan bantuan dari program SPSS. Hasil dari regresi dan SPSS tersebut menunjukkan bahwa, hipotesis 
pertama pada model penelitian ini diterima dan telah dinyatakan valid. Bahwa adanya Intention atau niat dari pengguna berpengaruh kepada adanya Illegal Movie Streaming. Selanjutnya, hipotesis ketiga yang telah kami ajukan juga bersifat valid, yaitu dengan adanya aksi Habit atau kebiasaan dari pengguna atau mahasiswa Kota Batam, dapat membuat film menjadi semakin popular atau terkenal, yang penyebarannya dimulai dari lingkungan terdekat, lalu menyebar secara meluas ke luar. Namun, Deficient Self Regulation tidak diterima karena tidak berpengaruh secara langsung terhadap aksi Illegal Movie Streaming. Hal itu disebabkan karena kegiatan Illegal Movie Streaming ini merupakah hal yang sudah dianggap biasa untuk dilakukan, terutama bagi Mahasiswa di Kota Batam.

Uji R Square pun kami peroleh sebesar 0.778, Uji $F$ sebesar 403.945, yang berarti bahwa model yang kami gunakan pada penelitian ini cocok dengan fenomena yang ada. Uji data ini juga memperoleh nilai Durbin Watson sebesar 1.631.

Pada penelitian ini, Uji Realibitas menggunakan Cronbach's Alpha dapat dibuktikan semua construct pada penelitian ini dianggap reliable, dengan semua nilai berada di atas 0.6.

Uji regresi juga kami lakukan dengan persamaan: Illegal Movie Streaming $=(0.21)+$ $($ Intention * 0.385) $+(D S R * 0.110)+($ Habit *
0.462) Dari persamaan regresi tersebut, dapat diperoleh nilai konstanta pada variabel dependen Illegal Movie Streaming mahasiswa Kota Batam awalnya sebesar 0.21, telah meningkat menjadi 1.167 dengan adanya variabel Intention, Deficient Self Regulations, dan Habit. Hal ini menunjukkan bahwa awalnya memang sudah banyak yang melakukan Illegal Movie Streaming di kalangan Mahasiswa di Kota Batam, tetapi kegiatan tersebut pun meningkat karena dengan adanya niat, regulasi diri dan kebiasaan dari mahasiswa. dapat meningkatkan aksi Illegal Movie Streaming. Dimana akan meningkatkan popularitas dari film-film yang ditonton tersebut, karena adanya penyebaran informasi mengenai film dari satu pihak ke pihak yang lain secara terus-menerus.

\section{DAFTAR PUSTAKA}

1. Apriyani, T. (2020). Pengaruh E-Commmerce Terhadap Pertumbuhan Ekonomi Indonesia. Suara.Com.

2. BP Lawyers. (2018). Hak Cipta : Mengenal Lebih Dalam Hak Cipta di Indonesia. Bp Lawyers.

3. Burdatun, B. (2016). Penegakan hukum terhadap. Jurnal IUS, 4(4).

4. Indonesia, C. (2020). IndoXXI Disebut Kelola Jaringan Situs Pembajakan Film Dunia. CNN Indonesia. 
5. Kim, A., Lahiri, A., \& Dey, D. (2018). The "Invisible Hand" of Piracy: An Economic Analysis of the Information-Goods Supply Chain. MIS Quarterly: Management Information Systems, 42(4), 1117-1141.

6. Raharjo, paksi suryo. (2018). Berantas Tuntas

Pembajakan Film. 07 Agustus 2018.

7. Silaban, M. W. (2019). Batam Dorong Industri Film Lokal Tembus Pasar Asia.

Tempo.Co.

8. Sutadi, H. (2010). Sejarah Film dan Perkembangan Film Indonesia. Kompasiana.
9. Wijiharjono, N. (2018). Tumbuh Kembang Remaja dan Permasalahannya. 1-24.

10. Wikipedia. (2020). Media streaming. In Wikipedia.

11. Yeh, B. T. (2012). Illegal Internet Streaming of Copyrighted Content: Legislation in the 112th Congress. Legislative Approaches to Online Piracy and Copyright Infringement, 1-19.

12. Yougov. (2019). 24122019-ILLEGALSTREAMING-IN-INDONESIA. 